\title{
Conservation of Property Rights of the Person Declared Missing
}

\author{
Valbona Alikaj, Phd candidate
}

Lecturer at the University "Ismail Qemali" Vlore, Albania

\section{Doi:10.5901/ajis.2013.v2n9p290}

\begin{abstract}
As our society develops rapidly, there are issues affecting probably every day families all over the world, as kidnapping and trafficking, hostage-taking or slavery. But sometimes the absence of a person for a long time might be a choice because the way of living has become far too individual and independent, despite many ways to maintain contact and communication with familiars and friends. These situations need to be regulated, and it is legislation's role to provide temporarily solutions, as the situations thought and hoped to be temporarily. Declaring the missing of a person is a legal provision under well defined terms and conditions. This paper aims to explain the important role of this institute, seen as a guarantee to the protection and conservation of property rights of a person declared missing. The paper will underline the highlights of this institute, analyzing the provisions of the Albanian civil legislation, comparing them with the provisions of foreign legislations and taking in consideration judicial solutions. It will be noted especially the publicity that accompanying the procedure of declaring a person missing and the different regulations of personal and property rights of the missing people till his declaration or the possibility of his return.
\end{abstract}

Keywords: missing person, the administration of the right, property, returning the rights

\section{Introduction}

Back in time we see that one of the ancient Roman institutions is: postliminium. Roman citizens could lose the status of a citizen with the loss of freedom (deminutio maxima capitis). Roman citizens captured by opponents and return to slavery loss the Roman citizenship, but if the slave would be released he would enjoy the right to return to Rome. According to the legal institution postliminium he would be seen as a subject who has never lost citizenship, the right to freedom and other basic rights. (Novitskiy I.B., Pereterskogo I.S. 2000)

Despite economic conditions, social and social development in Albania and abroad still remains problematic the absence of persons and declaring them dead. Thus, nowadays are known cases of hostage taking, kidnapping and trafficking, keeping them isolated for a long time and use them as slaves. Persons ages and from all Walks of life go missing in many Different circumstances and for Different Reasons. (Missing People, 2008).

Analyzing the institute of "declared a person missing" is of a highest interest in particular for the Albanian case referring to social and economic developments, as well as the multitude of reasons that led to its application. If we refer to the communism area in Albania the main reasons led to the absence of persons were; the closing of state borders and escapement without notifying family members, in order to avoid the negative consequences of "crime"; the disappearance of political opponents regime and infiltration of people in the state intelligence abroad.

In the early 90's the main reasons for the disappearance of persons were linked to the massive migration and "dangerous" forms of getaway. Number of persons declared missing increased as a result of criminal phenomena related to the trafficking of children for the beggar, organ transplant and girls for prostitution to European countries. The consequences of the absence of these persons increased the number of requests to the court to declare their missing.

The treatment of the property and personal consequences is of particular importance because the institute affects not only the missing person, but at the same other persons who stay connected in a relationship with him. The social relations of a property character, as well as other social relations that are not considered initially as property but which ultimately they can also be expressed in a property value, are legal relationships guided by law. (Nuni A. 2009)

Since the consequences of the declaration of the person missing are not equated with death, is possible and expected the reappearance of the person and the possibility of regaining back his rights.

\section{The Institution of "Declared Missing"}

A "missing person" is a natural person whose existence has become uncertain, because he or she has disappeared 
without trace and there are no signs that he or she is alive. (CM/Rec 2009)

The legislation provides the terms, conditions and procedures set to declare a person missing, despite of the circumstances in which the person is disappeared from the residence or domicile. The lack of news and lack of information is considered an essential requirement to qualify a missing person. Family members or state authorities treat the absence as a presumed situation in which the person can be due to the inability to contact him. The reasons that can lead a person to be considered as missing are due to; avoidance of contact with consciousness as a result of family conflicts or performing criminal acts or failure of various legal obligations, but can also be connected to the impossibility for real contact, where the most unfortunate case would be his death.

The absence of the person does not necessarily mean disappearance from the domicile, but may occur as a result of extremely dangerous situations: "Missing person is a person whose whereabouts are unknown to his/her relatives and/or who, on the basis of reliable information, has been reported missing in accordance with the national legislation in connection with an international or non-international armed conflict, a situation of internal violence or disturbances, natural catastrophes or any other situation that may require the intervention of a competent State authority". (Guiding principles)

In these cases The Albanian Civil Code "avoids" the common procedure of declaring a person missing, because it provides the possibility of declaring the person dead, precisely of the dangerous circumstances and the great probability of the death of the person.

The concept of contact should be evaluated not only as an unilateral effort, but even as the efforts made by family members, state authorities and other interested persons to request information and get informed on the situation.

"The person who is absent from the place of residence or his last domicile and for which there is no news for more than two years, at the request of any interested person may be declared missing by the decision of the court.". (Art. 18, 19 of the Albanian Civil Code)

The interpretation of the article clears out a two-year term, appointed by the legislator for the realization of contact. This term is reasonable and sufficient to news received by the person, but at the same time also sets a time limit for all concerned, not to invest the court immediately. When the day of the last news cannot be determined, the above deadline begins from the first day of the next month in which they got the latest news. When the month cannot be determined, the period starts from 1 January of the following year. (Art 18, 19 of the Albanian Civil Code)

The request to declare a person missing or dead may be submitted by any interested person and the prosecutor in the court where he last resided. (Art 375, of the Albanian Procedural Civil Code)

The term "interested person" is not defined either in the Albanian Procedural Civil Code, or in the Albanian Civil Code. Interpreting the law among "interested persons" shall be the spouse who may be interested for dissolution of marriage, parents and children, who are directly affected by the disappearance or death of their relative, or persons who are more interested in finding the truth or persons in charge of the absent person. (Curi P. 2008).

Persons interested in declaring a person missed, may also be other persons, who may be interested to protect their violated rights or to protect their interests by law (for example, lender, tax authorities), and the prosecutor, public authorities and individuals, as they are entitled to protect the rights and interests of others. (Yarkov V.V. 2003) As stated above, it is understood that persons who are defined as "interested", have common interests to seek the declaration of the missing person. This interest should be a legitimate interest, in order to be considered by the court.

The amendments adopted in the Albanian Civil Procedure Code, which enter into force in September 2013, include to the order of the persons concerned, the attorney with whom the person has edited a notarized will or deposited a special will for safekeeping. (Art 28, of the Law No. 122/2013 amending the Albanian Civil Code)

The declaration of the missing person is made by the court. The court declared the missing person only when is convinced that there are no news for real and there is no other way through which to provide the news. When declaring the missing of a person, the court sets custody for the administration of his estate. The decision of the court, by which a person is declared missing must be published in the Official Journal and submitted for registration to the respective civil registry office because the declaration of missing is component of the civil status of the person. (Civil Status Law) In the request to declare a person missing or dead, except of the circumstances in which becomes reliable the disappearance or death, should be included even the custody or his legal representative. (Art380 of the The Albanian Procedural Civil Code)

The Spanish legislation provides two phases in the procedure of declaration of missing person:

- Presumption of absence, known as temporary stage. This phase aims to "address the most urgent issues that can arise". (De Cossío A. 1977). For the person who interrupts the relations with his relatives and where there is uncertainty about his location can bring a situation that requires immediate action to be taken to managing the wealth of the absent person. Article 181 of the Spanish Civil Code provides the right of the court 
to appoint a representative to the missing person in order to protect his legal interests and legal negotiations and to prevent any damages that may arise. The judge may also impose other measures to achieve protection of legal interests. To implement these measures the Civil Code requires no information by the person who is absent.

- Declaration of missing, also known as the phase of legal absence. It is performed at the request of the interested party, "Persons who enjoy the right on the property of the person who is missing...". (Bonnecase J. 2001) (Partners, creditors, spouse, heirs). (García M.J.B. (2005) The Court examines all documents, and requires to the General Prosecutor to verify the relevant information.

Even the Italian legislation provides two phases in the procedure of declaration of missing person:

a) The absent, which is a factual situation during which the person is missing in his domicile. At this stage the person is not declared missing but persons who are interested may request the appointment of custody by the court to administer the property of the absent person.

b) Declaration of missing that is not only factual, but at the same time a legal situation. (Article 49 , of the Italian Civil Code) Consequences that come as a result of the declaration of the person missing in Italian legislation are different from the Albanian legislation. According to Art. 50 of the Italian Civil Code, the declaring of the person missing brings these consequences:

- His heirs can take temporary possession of property of the missing person

- Disappearance leads not to the end of the marriage, but the spouse can have a new marriage which cannot be attacked for invalidity as long as the person will be missing. (Article 50, of the Italian Civil Code)

The French Civil Code does not provide the declaration of death, despite the time that may have passed from the moment of his absence from the residence. This is due to the political expansion that Napoleon undertook in the territory of Europe and abroad. The soldiers, who went to war, should be given certainty that when returning from it they would enjoy the same rights on the property and their marriage would continue to exist.

According to the article 112 of the France Civil Code, where a person has ceased to appear at the place of his domicile or residence and has not been heard from, the judge of guardianships may, on the application of the parties concerned or of the Government procurator, establish that there is presumption of absence. The judge may designate one or several relations by blood or marriage or, where appropriate, any other persons to represent the person presumed absentee in the exercise of his rights or in any act which would be his concern, as well as to administer all or part of his property ; the representation of the presumed absentee and the administration of his property shall then be subject to the rules which apply to statutory administration under judicial supervision such as it is provided for minors and, in addition, under the following amendments. (Article 113, of the French Civil Code)

\section{A Comparative Analyze on the Conservation of Rights of the Person Declared Missing}

Preservation of the rights of the person declared missing is an important provision that aims to evaluate the possibility of his return. The publicity that is made with the publication of the court decision to declare the missing person in the Official Journal gives to the person an opportunity to become aware of what was happening in his absence.

"The decision of the court which declares a person missing must be published in the Official Journal and submitted for registration to the relevant civil registry office". (Article 16 of the Albanian Civil Code)

With the registration of the court decision in the Civil Registry Office, the institute starts to manifest its legal consequences. Just to protect the property rights of the person declared missing the court appoints custody for the administration of his property. (Paragraph I, article 16 of the Albanian Civil Code) The court may also take measures to ensure the property under circumstances that make it necessary to take them. (Article 380 of the Albanian Procedural Civil Code)

The Spanish Civil Code provides that the representation of the person declared an absentee, the investigation of his whereabouts, the protection and administration of his property and the performance of his obligations shall correspond to the present spouse of legal age not legally or de facto separated from him, his child of legal age; if there should be several, those who lived with the absentee shall be preferred, and an older child shall be preferred over a younger child, the nearest youngest ascendant of either line, siblings of legal age who have cohabited as a family with the absentee, with preference of older siblings over younger ones.

In the absence of the aforementioned persons, such representation shall correspond, in all its scope, to the solvent person of good background designated by the Judge at his prudent discretion, after hearing the Public Prosecutor. 
The Spanish Civil Code has clearly defined the obligations "The representative of the person declared an absentee shall be subject to the following obligations:

1. To make an inventory of movable property and to describe any immovable property of his principal.

2. To provide the bond prudentially set by the Judge. The representatives included in numbers 1,2 and 3 of the preceding article shall be accepted.

3. To preserve and defend the assets of the absentee and obtain from his property any normal returns of which it is capable.

4. To comply with the rules provided in the Civil Procedural Law relating to possession and administration of the absentee's property.

The provisions governing the exercise of guardianship and grounds for ineligibility, removal and excuse of guardians shall apply to the appointed representatives of the absentee, to the extent that they are adapted to their special representation. (Article 185 of the Spanish Civil Code)

One of the legal consequences that bring the declaration of the missing person may be even the termination of the marriage but the Albanian legislation doesn't provide such consequence. One of the conditions of marriage termination is by the declaration "dead" of one of the spouses but the legislation doesn't provide such consequences in cases of declaration of a person missing. In such case there is no "breach" of the continuity of marriage. This provision doesn't include the marital property regime. According to the New Family Code, article 96, the declaration of a person "missing" entails the termination of the legal property regime between the spouses and of any other marital property regime. On this fact the Albanian legislation provides that "A person who is declared dead regains all his property or personal rights from the person who has passed these rights". (Article 124 of the Albanian Family Code)

The termination of the property regime and its division that will be in according to the type of regime chosen by the spouses is justified by the fact of establishing custody for the administration of the property of the missing person.

The Italian legislation seems to be more careful in preserving the rights of the person declared missing in the event of his reappearance. Under the title "Termination of the effects of declaration of a missing person" art 56 of the Italian Civil Code provides the regaining of the rights of the person who reappears or in case there is evidence that this person is alive. According to Art 56, the person who is declared missing, regains all of his property rights which are in temporary possession of "his heirs", except when his absence was intentional or unjustified. (Article 56 of the Italian Civil Code)

\section{Recommendations}

It can be said that studying the institute of declaring a missing person has a special importance in nowadays. The main reason of treating and studying this institute is that, it legally constitutes the first phase of the declaration a person dead after the fulfillment of the term.

By applying the institute the law provides a guaranty for the administration of the missing person's property and preserves his personal rights.

In comparative aspect with foreign legislation, the Albanian legislation has deficiencies in providing and regulating the institute of declaring a missing person in details. Based on the legal experience in this area of some European states legislation, I recommend some amendments:

- The article 375 of The Albanian Procedural Civil Code provides the right to make the request to declare a person missing or dead to any interested person, the prosecutor and by recent legal amendments even the attorney, without determining who may be the persons interested in. It would have been more accurate if the law defines the categories of the persons that would have been legitimized to make such a request.

- Referring to Spanish legislation which provides the categories of persons who may be custodies or legal representatives of the person declared missing and defines even their powers, the Albanian legislation does not have any similar provisions, so that this may lead to abuse not only in selecting the custody, but even in his obligations.

- Regarding to the Albanian family legislation and considering the procedure of declaring a person dead as a long procedure, at least about seven years, it may be reasonable the provision of a possibility of dissolution of marriage in case one of the spouses is declared missing. This would not be the same as if one of the spouses would have been declared dead because the marriage ends automatically, but to be designated as a right or opportunity of the other spouse to decide the fate of the marriage. 
- The Albanian legislation, like the Italian Legislation, must contain provisions if a person misses intentionally, as penalties, to prevent possible abuses.

\section{References}

Novitskiy I.B., Pereterskogo I.S. The jurisprudence. Moscow, 2000

Holmes Living in Limbo: The Experiences of, and Impacts on, the Families of Missing People (London: Missing People, 2008) at 11, retrieved from www.missingpeople.org.uk.

Nuni A. E Drejte Civile I, Tirane, 2009

Recommendation CM/Rec (2009)12 of the Committee of Ministers to member states "On principles concerning missing persons and the presumption of death"

Guiding principles / Model Law on the missing, Principles for Legislating the Situation of Persons Missing as a Result of Armed Conflict or Internal Violence: Measures to prevent persons from going missing and to protect the rights and interests of the missing and their families.

Curi P. E drejta Proceduriale civile \& Noteria, Tirane 2008

Yarkov V.V. The subjects of law in the mechanism of implementation of the rules of civil procedure law, Saint Petersburg; Piter Publishing Company. 2003,

Ligj Nr. 122/2013, date 18.04.2013 "Per disa shtesa dhe ndryshime ne Ligjin Nr. 8116, date 29.03.1996 "Kodi i Procedures Civile te Republikes se Shqiperise", te ndryshuar

Ligji Nr. 10 129, datë 11.5.2009 "Për gjendjen civile", i ndryshuar

De Cossío, Alfonso. Instituciones de Derecho Civil, Vol. 1. Ed. Alianza. 1977

Julián Bonnecase En el tratado de derecho civil supracitado Vol.1, Seria I, Ed. Oxford. 2001.

La ausencia y desaparición en la legislación dominicana / Manuel de Jesús Brito García (Santo Domingo : PUCMM-RSTA, 2005).

The Italian Civil Code

The French Civil Code

The Albanian Civil Code

The Spanish Civil Code

The Albanian Family Code

The Albanian Procedural Civil Code 